\title{
わが国の紫外線研究の歩み $(\mathbf{1})^{\dagger}$
}

\section{1. まえがき}

1801 年にドイッ人 J. W. Ritter が太陽光の可視域ス ペクトルを研究しているときに，短波長端からはずれた 所に強く写真作用を起こすものがあることを知った。 こ れが紫外線発見の最初である.次いで Thomas Young （英）が 1804 年にこれを電磁波の一環として把握した. その後, 欧米の研究者によって研究が大いに進み, M. Luckiesh $^{1)}$ 忽よび L. R. Koller ${ }^{2)}$ の二著書の中にその詳 細が述べられている。

わが国では1929 年（昭和 4 年）に，山田幸五郎 ${ }^{3)} の$ 著書 “紫外線”が公刊されて一般に紹介されたが，分光 学の分野では, 紫外域スペクトルは研究の常套手段であ って, これによって原子構造が解明し, 量子論, 量子力 学がめざましい発展を遂げた。ここでは分光学に触れる ことなく，照明工学の中でのわが国の紫外線 研究の跡 を, それも終戦後の発展について, 研究外史の形でたど ってみる.

話に先だって紫外線を Koller に従って，次のように 分類して打く.

$\begin{array}{lr}\text { 近紫外 } & 300 \sim 400 \mathrm{~nm} \\ \text { 遠紫外 } & 200 \sim 300 \mathrm{~nm} \\ \text { 極端紫外 } & 40 \sim 200 \mathrm{~nm} \\ \text { シューマン領域 } & 122 \sim 185 \mathrm{~nm}\end{array}$

\section{2. 殺菌灯の発達}

第二次大戦が終わって文献を調べてみると，欧米特に アメリカに护歪菌灯の普及発達に驚かされた。そこ で原田常雄が中心になって追跡研究が始まった。まず石 英殺菌ランプによる細菌実験4)が行なわれ，昭和 25 年 には東芝および三共から製品が出た。しかし石英管製は 材料が高価であり，オゾン臭が強くて扱いにくく，かつ 製造が困難で量産にもかないといら久点があるために，

† History of Researches on Ultra-violet Rays in Japan(Part I ) * 東京芝浦電気晽照明事業部
専門会員参与 東堯*

ついに小規模生産だけで終わった。 まをく $253.7 \mathrm{~nm}$ の水銀共鳴線をよく透過する特殊ガラスが開発され，乙 れを使っての 細菌実験 ${ }^{5}$ を経て, 昭和 27 年には東芝, 三共および島田硝子から, さらに少し遅れて松下電器, 三菱電機からガラス殺菌ランブの製品が現われた。

殺菌ランプはけい光ランプに類形の構造をもち, 中味 は低圧水銀放電であって, 強力な水銀共鳴線 $253.7 \mathrm{~nm}$ をそっくり空中に放出させるランプである. $15 \mathrm{~W}$ の入 力に対して $2.9 \mathrm{~W}$ が一つのスペクトル線に集中して出 るといらすぐれた性質がある。この波長が殺菌効果のス ペクトル分布のピーク $(260 \mathrm{~nm})$ にきわめて接近してい るためにに，殺菌ランプはきわめて効率のよい殺菌要素 となる.これは光線殺菌であるから，化学薬品や加熱な どによる殺菌方法と異なって，被照射物照射後に医とえ ど変化を残さないといら特徵がある. 紫外線殺菌は柴外 線透過のよい空気と水の堿菌に有効であり, 物品に対し て表面の消毒に有効である，殺菌ランプおよびその反射 器具の開発, 各種の殺菌効果の奏験, 殺菌灯使用の設計 などに関して幾多の研究6ー14) が発表された。 その間の トピックスを拾ってみる.

(1) 昭和 30 年代のある日，東京上野のIビルが換気 用のエアダクトに殺菌灯バンクを取り付けた。たまたま そのダクト内を工事することがあって，工事人数名が照 明のために殺菌灯を点灯した。ところがその晚，その全 員が猛烈な電気性眼炎に犯されて，目がはれ上がって大 騒ざになった，といら新聞記事が全国に報道された。幸 い失明者はなく数日して全員回復したが，殺菌ランプが けい光ランプと類形であり, 簡単に取り扱えるために起 こった悲劇であった。

（2）殺菌灯普及の一時期に “光再活事件”が起こった. これは殺菌柴外線照射によって死んだと思われた細菌 を，可視光線で強く照明すると活性を取り戻すという現

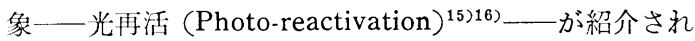
て，殺菌ランプ無効論が起こりかけた。しかし，光再活 には線量還元の法則 ${ }^{9) 16)}$ (Dose-reduction principle) が 


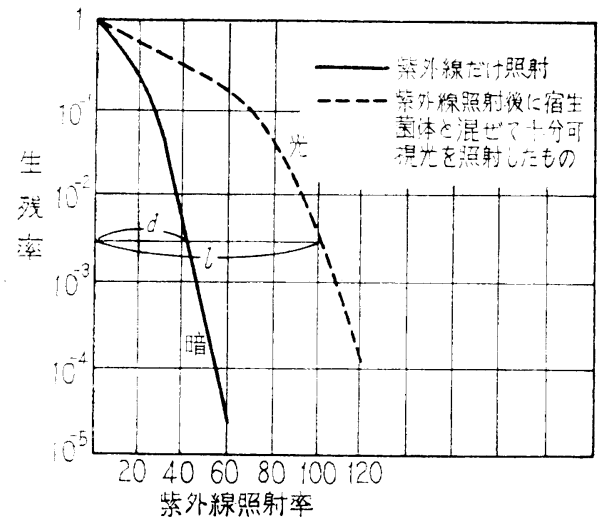

図 1 大晹菌 $(\mathrm{B} / \mathrm{\gamma})$ の生残事曲竬16) $\mathrm{B}$ : ベクテリオフーー (宫生ビールス) $\gamma:$ 放身線抵抗性菌

成り立つ，図１に沶いて生残率の等しい值で比較する $亡$, 線量 $l$ の殺菌線照射を行なった後に可視光線を十分

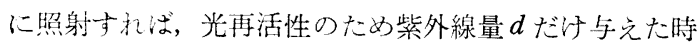
之同じ殺菌効果化変わる。すなわち, 可視光線が殺菌照 射量を $d / l$ 汇減らすよらな動きをする. $l / d$ を線量還元 率といらが，この值は任意の生残率において一定であっ て，大腸菌の場合 $2.1 \sim 2.5$ 之報告されている. この法 則を使えば，暗中で行なら紫外線照射量の 2.5 倍くらい 余分に照射してやれば，蘇生効果は消えることがわかっ て，上記の無効論は消え去った。

(3)殺菌灯の使用を義務づけた省令がある。それは厚生 省令第 42 号 ${ }^{17}$ であって，理容師法施行規則を一部改正 Lて, 紫外線消毒 (20 分間以上 $85 \mu \mathrm{W} / \mathrm{cm}^{2}$ 以上の紫外 粕を照射することをいら）を付加している。これによっ て全压の理髢店に殺菌線消毒器が装備された。

(4) 省令までには至らなかったが，日本食品衛生協 会 ${ }^{189}$ の推奖によって, まな板殺菌灯装置が多くの旅館調 理公に装備された。これはアルマイト加工による乱反射 面をもった大きな反射がさに殺菌ランプを取り付计たも ので,これによってまな板を照射し，包丁による伤跡の 内郤まで殺菌線照射するように設計したものである。

(5)四連規格として殺菌用低圧水銀放電管と，殺菌紫 外線の測定方法とが ${ }^{19)}$ JISになっている.

殺菌ランプは畜産にも利用されるよらになり, 養舀,

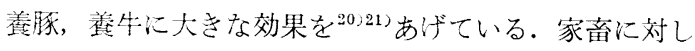
て健康紫外線も有効であるため, 殺菌ランプの管の内面 に徤康線用けい光体を薄く塗付することによって，両方 の紫外線を図 2 のよらに，いっしょに放出する養鷄灯 22) 24)が開発された。

殺菌ランブは公害対策に活用される様子である。合成 洗剂による河川，下水の污染の中で生物化学的に分解不 可能な ABS (Alkylbenzenesulfonates) が, $253.7 \mathrm{~nm}$

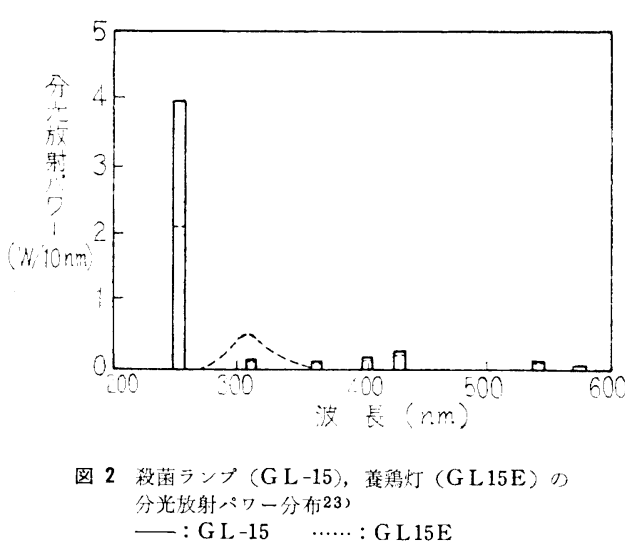

紫外線の水中照射によって光分解を起こすことが研究 ${ }^{24}$ されたことに基づく、塩素を含む酸化剤を混ぜることに よってこの光分解は顥著に促進される.

\section{3. 健康に役だつ紫外線}

波長 $280 \sim 310 \mathrm{~nm}$ 範围の紫外線は人間の皮虞に紅は ん(斑)作用を起こすと同時に，体内でェルゴステロール からビタミンDを生成して, その効果, くる(佝瘦)病の 子防や治療，鉣物質の代謝を促進する効果が顕著である ので，健康線またはドルノー（Dorno）線と呼ばれる。 紅はんの分光作用曲線は欧米で研究されて, 図 3 の中 の $280 \mathrm{~nm}$ に谷のある曲線として標準化された。わが国

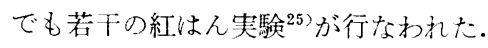

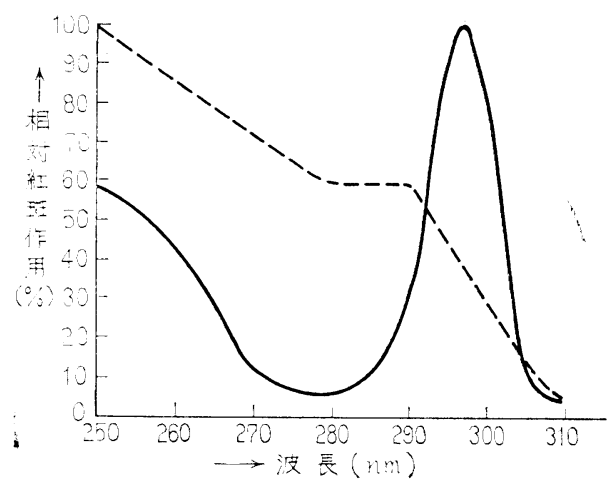

図3紅は九作用曲和 $\ldots$ : IES 標準
$\cdots \cdots:$ : Everett

この分光作用曲線に基づいて, 戦前には白熱電球によ る健康ランブとして，バイタライトが開発されたけれど も，その紫外線はわずか26)であるためにあまり普及せ ず，後にはむしろ赤外線を使うことを考えて，インフレ ッド・ユニットと呼ばれた. 戦後けい光ランブの発達に つれて健康線用けい光シンプが開発された. $300 \mathrm{~nm}$ り短波長の紫外線は目に有害であるので, ドルノ一線ぎ りぎりの $280 \mathrm{~nm}$ までの紫外線を透過与るガラス管を使 
ったもので，しかも使用にあたっては保護のため, めが ね(普通のガラスでよい) をかけることを要請してい る. 保健㧍よび治療 ${ }^{27) ~ 297}$ に相当の効果があり,さらに

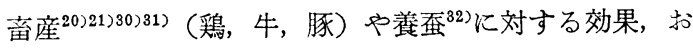
よび農産物 ${ }^{33)}$ (しいたけ）に対するVD付与効果があっ て普及している。

最近になって紅はんの分光作用曲線について， M. A. Everett ら ${ }^{34)}$ から異論が現われ，280 nm で曲線が下がる ことを否定して，図 3 の中の破線曲線が正しいと唱えら れた。国内でもこの反論を支持 ${ }^{85}$ する研究が行なわれて いる. 前の曲線も多数の研究者がそれぞれ独立に研究し た結果をまとめたものであって，アメリカの照明学会 ${ }^{36)}$ では今日でもそれを支持している。この議論は医学的検 討を樑める必要があり，十分な研究によって信頼できる 結論を引き出して欲しい。

紅はんの分光作用曲線はさておいて，290 nm までの 紫外線之可視領域とについて, 自然昼光と分光分布の一 致したけい光ランプが開発されて，太陽汁い光ランプ37) 之名つけられた。 その分光パワー分布は図 4 のと括り で，可視部は真天然昼光色汁い光ランプと同等であるか う, 平均演色評価数 $R_{a}=92$ である. これはけい光色材 を含めた試料に対する色評価用にる, 健康紫外線を補っ た一般照明にも使うことができる。

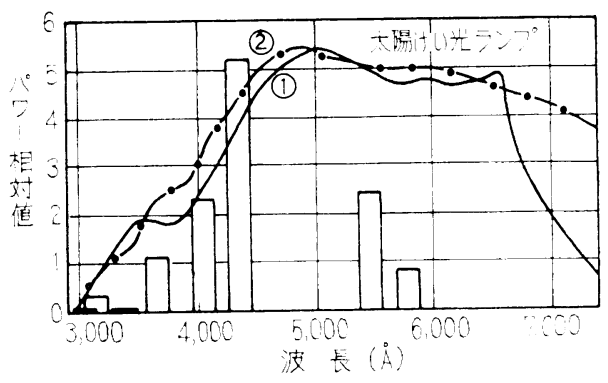

図 4 太陽计い光ランプの分光分布 37 (1) 太陽けい光ランプ (2) 自然昼光 (Schulze)

これとは別に，一般照明用として最も普及している白 色または㡺光色けい光ランプに健康紫外線を少し添加し

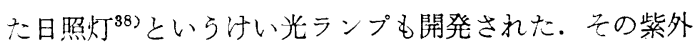
線量快, 照度 $500 \mathrm{~lx}$ の下 8 時間かかって MPE (Minimum Perceptible Erythema Dose, 最近は MEDすな わち Minimal Erythema Dose ともいう) の約 1/8に なるように設計されたものである. 日照不足の地下街, 大ビルの内部，または日照の悪い個人家屋の照明に好適 とされている.

\section{4. けい光ランプ紫外線に関する論争}

けい光灯照明が職場から家庭へ急速にひろがっていっ た一時期に，けい光ランプから紫外線が出てそれによっ
て目が痛められるという学説が, 新聞紙 ${ }^{39}$ 上にも報道己 れて，それを否定する立場との間に相当激しい論争が㐫 った。

有害説を唱えたのは大塚任40)であって, 臨床症例から けい光ランプから出る紫外線は目に障害を起こすから， 至急対策をとらなければならないと警告した。これに対 して蒲山久夫 ${ }^{41)}$ は眼科生理学の立場から反論し, 波長 $300 \mathrm{~nm}$ 以上の紫外線は角膜に損傷を与えず，紫外線は 水晶体を損賃することはなく，健康な目に対してけい光 ランプが紫外線角膜炎を起こすことはないから，汁い光 ランプは目にとって無害であるとした.

浜野光 ${ }^{42)}$ は眼科実験によって反論し, 家東眼に対する 照射，人眼に対する照射拉よび臨床的観察のいずれにお いても,けい光ランプからの紫外線 310〜400 nm 恃全? 目に障害を与兄ていないと結論した。特に人眼に対する 実験には,ブラックライトけい光ランプによる近距離照 射も含めていて, $310 〜 400 \mathrm{~nm}$ の紫外線のいかなる量に よって眼障害を起こすか，その限界を実験的に決定した い希望をもって行ったのであるが，普通の場合の数百倍 にあたる大量でも全く眼障害が見られなかった。

中西定典 ${ }^{43)}$ も，家乐眼拉よび人眼に対して追試実験 を行なってけい光ランプから出る紫外線の無害を実証 した。

東尭, 芋谷暁史郎ら ${ }^{44)}$ は, けい光ランプ各種の紫外域 まで含めた分光パワー分布を新しく測定し， $310 \mathrm{~nm}$ 以 下に紫外線が出ないことを明示して, 照明工学的立場か ら，紫外線に関してけい光ランプは太陽光ないし昼光上 り一層安全であると結論した。このようにしてこの論争 は落着した。

\section{参考文 献}

(1) M. Luckiesh : "Application of Germicidal, Erythemal and Infrared Energy" (1946)

(2) L. R. Koller : "Ultraviolet Radiation" (1952)

(3) 山田幸五郎：紫外緊（昭 4)

（4）原田常雄, 富樫実, 芋谷暁史野: 殺菌灯について 東芝レビュー 4 (昭24) 43; 殺菌灯(1) 照学誌 34 （昭25） 169

(5) 原田常雄, 木村徳三郎, 白石啓文：殺菌灯(2) 照 学誌 34 (昭25) 196; 東芝レビュー6(昭26) 287

(6) 原田常雄: 殺菌灯 照学誌 36 (昭27) 23

（7）河端俊治, 原田常雄：殺菌灯による水の消毒 照 学誌 36 (昭27) 89

（8）浅野澄忠，木村款二：低圧水銀灯による殺菌につ いて (空気殺菌) 照学誌 34 (昭25) 362

（9）東 堯, 白石啓文: 殺菌灯とその応用 東芝レビ 工 11 (昭31) 1019 
(10) 白石啓文：殺菌灯照射による水の殺菌について 照学誌 43 (昭34) 48

(11) 白石啓文：空気衛生を目的とする殺菌灯器具取付 数の算定について 照学誌 45 (昭36) 513

(12) 東 葑, 白石啓文：柴外線殺菌灯と乞の応用 食 品衛生学誌 2 (炤36) 10

(13)大泉 淳, 鶴尾 勉: 最近の殺菌灯とその応用 東芝レビュー 17 (昭37) 847

(14) 河端俊治：水産物特にかきの処理用水の紫外線殺 菌 照学誌 53 (昭44) 128

(15) A. Kelner : Proc. Nat'l. Acad. Sci. 55 (1949) 73 ; J. Bact. 58 (1949) 511

(16) 西脇 安, 玉城 進: 可視光線による微生物の蘇 生 科学 22 (昭27) 575

(1i) 宫報（昭36.10.18）厚生省令第 42 号

(19) 日本食品衛生協会の紫外線殺菌研究部会調査研究 答申 1 (昭28.6.25)

19) JIS C 7605 : 殺菌用低生水銀放電管; JIS Z 8811 : 殺菌紫外線の測定方法

(20) 䈎本 馨：養鷄と養亘に対する紫外線応用 照学 誌 53 (昭44) 132

(21) 松川誠夫：家音 照学誌 53（昭44） 136

(22) 河本康太郎：日生環調学会 9 回大会 (昭46), Toshiba Review Intern. Ed. No. 39 (1968)

(23) 東 圭, 白石啓文, 河本康太郎：生物産業亡照明 技術(1) 東芝レビュー26（昭46） 790

(24) 金山忠雄, 小林 正：紫外線による水中のABSの 分解 東工試報告 63 (昭43) 117

(25) 原田常雄：健康線用けい光灯 照学誌 37 (昭28) 157 ; 東芝ンビュー 8 (昭28) 241

26) 東 琴，芋谷暁史郎，梅川 梅：熱輻射光源の健 康線量 照学誌 27 (昭18) 3

27) 日野和徳, 高井光子：健康線用けい光灯の効果試 験(1) 照学誌 38 (昭29) 150

(28)日野和德，高井光子：健康線用けい光灯の効果試
験 照学誌 41 (昭32) 47

(29) 田坂重元, 田宮恭子：乳奻児に対する健康線用计 い光灯照射の効果 照学誌 42 (昭33) 419

(30) 笹本 馨, 小林正己：畜産の研究 2(昭42) 1443

(31) 宾戸弘明, 野崎 博：光の家畕, 家禽に及ぼす影 響 照学誌 53 (昭44) 98

(32) 笹本 馨, 森川 勇：ドルノ一線照射による寔の 飼育 照学誌 43 (昭34) 224

(33) 有本邦太郎，佐土根範次湾：健康線照射による しいたけのビタミン $\mathrm{D}_{2}$ の生成 照学誌 53 (炤 44) 124

(34) M. A. Everett, R. L. Olsen, R. M. Sayer : Ultraviolet Erythema, Arch. Dermat 92 (1965) 710

(35) 佐藤吉昭：本特集号揭載論文

(36) IES Lighting Handbook 5th Ed. (1972) 25-16

(37) 東 堯, 白石啓文：けい光ランプ紫外線の制御 東芝レビュー19（昭39）799; Control of Ultraviolet Radiation from Fluorescent Lamps, ToshibaReview Intern. Ed. No. 22 (1965)

(38) 住幸二郎, 近藤顕賢, 白石啓文 : Sunlight Fluorescent Lamp-Nisshoto-, Toshiba Review, Intern. Ed. No. 58 (1971); 健康照明用けい光ラ ンプ「日照灯」東芝レビュー 25 (昭45) 1248

(39)産経新聞10月15日，10月18日（昭28）

(40) 大塚 任：计い光灯にいる眼障害 東京眼科集談 会 (昭28.8); 公荣衛生 14 (昭28) 95

(41) 蒲山久夫：眼とけい光灯 照学誌 37 (昭28) 391

(42) 浜野 光: 汁い光灯紫外線の眼に与える影響の有 無について 照学誌 37 (昭28) 432

(43) 中西定興, 岩崎俊策, 小松 真: けい光灯から出 る紫外線による眼障害について 照学誌 38 (昭 29) 245

(44) 東 堯, 芋谷暁史郎: け小光放電灯の紫外線 照 学誌 39 (昭30) 329

（受付 1973 年 3 月 7 日） 